\title{
Molecular Characteristic of Fusarium oxysporum from Different Altitudes in East Java, Indonesia
}

\author{
Henik Sukorini ${ }^{1, *}$, Erfan Dani Septia ${ }^{1}$, Lili Zalizar ${ }^{2}$ and Netnapis Khewkhom ${ }^{3}$ \\ ${ }^{1}$ Department of Agrotechnology, Faculty of Agriculture and Animal Science, University of Muhammadiyah Malang, Jl. Raya Tlogomas no \\ 246 Malang 65145, East Java, Indonesia; ${ }^{2}$ Department of Animal Science, University of Muhammadiyah Malang; ${ }^{3}$ Department of Plant \\ Pathology, Faculty of Agriculture, Kasetsart University, 50 Thanon Ngamwongwan, Lat Yao, Chatuchak, Bangkok 10900, Thailand
}

Received: Feb 20, 2021; Revised: May 28, 2021; Accepted May 29, 2021

\begin{abstract}
Tomato (Solanum lycopersicum L.) is one of the most economically important vegetable crops in Indonesia. Tomato diseases caused by fungi are transmitted by seed or transplants. Fusarium wilt disease is a cosmopolitan species caused by Fusarium oxysporum Schlecht. Emend. Snyder \& Hansen. Among this special attention of disease caused by F. oxysporum has been given to stem and root rotting. Six selected Fusarium samples from previous research were prepared using a single spore method and cultured in the PDB medium, The Research carried out in the Agrotechnology Laboratory of the University of Muhammadiyah Malang. DNA extraction and PCR used ITS 1 and ITS 4, electrophoresis, and data analysis was achieved at the Genetic and Molecular Laboratory of the Biology Department of the Faculty of Science and Technology, Maulana Malik Ibrahim Malang Islamic State University. Isolate code 3313439 originating from Karangploso soil (515 m a.s.l) and code 3313428 derived from the soil of Blitar (156 m a.s.l.) showed species similarity to F. oxysporum f. sp lycopersici strain CBS249.52. Then for sample 3313426, the roots of Pujon have similarities with the strain of $F$. oxysporum S58. Besides, samples of 3313422 Blitar roots, 3313424 Karangploso roots, and 3313432 Pujon soils (956 m a.s.l.) showed proximity to species F. oxysporum f.sp. pisi HG423346. The samples were in one clade with the nucleotide base sequences of two other F. oxysporum species recorded in the NCBI Genbank database. Differences in species will likely affect the pathogenicity, growth rate, spore production, and disease control management.
\end{abstract}

Keywords: Fungi, Fusarium wilt, Molecular Identification, Plant Pathology, Tomato

\section{Introduction}

Globally, one of the most economically important crops is the Tomato (Solanum lycopersicum L.) (AydiBen-Abdallah et al., 2020). Several economically essential tomato diseases caused by fungi are transmitted by seed or transplants. Fusarium oxysporum f. splycopersici Schlecht. Snyder \& Hansen (FOL) is the causal agent of fusarium wilt disease on tomatoes. It is a cosmopolitan species that can be found in all types of soil. Ignjatov et al. (2012) reported healthy plants could become infected by $F$. oxysporum if the soil in which they are growing is infested with the pathogen. FOL spread through short distances, mainly through irrigation water and contaminated farm equipment, and it can spread long distances through infected transplants, soils, etc. (Agrios, 2005). Special attention to disease has been given to the rotting of stems and roots caused by Fusarium sp. Based on the symptoms of the disease caused by Fusarium sp. indistinguishable. Control of this disease is alse still problematic. The use of chemicals such as methyl bromide is quite effective for disease management but impacts humans and the environment. The use of resistant varieties has also been carried out. This method is environmentally friendly but requires a lot of money. The ease with which pathogens form new strains and break the resistance of varieties causes this disease to be difficult to control (Xie et al., 2015).

Biju et al. (2017) reported three known FOL races (Races 1, 2 and 3) pathogens of tomato cultivars are distinguishable by their principle resistance genes. Races 1 and 2 are grown through the tomato-growing regions globally. Race 3 has been reported in countries such as California, Australia, Southwestern Georgia, and Mexico. Most commercial tomato varieties grown through the world are resistant to race 1 and 2, and a few are resistant to race 3. Certainly, once a region becomes contaminated with FOL, the fungus usually remains indefinitely (Animashaun et al., 2017; Prihatna et al., 2018). Pathogenic isolates from three different heights, namely low, medium, high altitude, have different colony colors, sporulation power, and growth rate. The ability to survive at high temperatures and resistance to Mancozeb $64 \%+$ Metalaxyl $8 \%$ and Benomil $50 \%$ fungicide also varies even though the growth inhibition value is below $60 \%$ (Henik et al., 2021). This, of course, will affect the success of controlling this pathogen. Therefore, molecular identification is required.

Identification can be made in two ways consisting of morphological and molecular character identification. Molecular character identification is based on the similarity of DNA (Alsohaili and Bani-Hasan, 2018)

\footnotetext{
*Corresponding author e-mail: hsukorini@yahoo.com.
} 
The genus Fusarium has often served as a testing ground for new speciation concepts in fungi (Hsuan et al. 2011). The use of molecular approaches to differentiate species has been tried with many strains usually considered problematic, i.e. not fitting within a given species but not distinguishable from it. Studies of the grouping patterns resulting from studies with amplified fragment length polymorphisms (AFLPs) and phylogenetic lineages based on multiple-gene genealogies provide new means of evaluating relatedness.

This research is a follow-up study from previous studies, namely the control of Fusarium sp wilt in tomato plants and Alternaria sp in potato plants. Henik et al. (2021) reported earlier studies, $F$. oxysporum from tomatoes originating from different altitude and parts of plants with spore shape and size characters. The same, but has other growth characters, so too has different pathogenicity and virulence. Therefore, it is necessary to reveal more about the differences in isolates from regions with different altitudes with molecular character identification.

\section{Method}

\subsection{Single spore isolation technique for F. oxysporum isolates}

Soil and tomato roots samples were taken from tomato growing areas in Blitar (156 m a.s.l.), Karangploso (515 $\mathrm{m}$ a.s.l.), and Pujon (956 $\mathrm{m}$ a.s.l.). After preparation, isolates were grown on PDA media (Merck). Then the isolates were made suspended and transferred to the water agar media. A suspension of conidia either from a sporodochium or aerial mycelium was prepared in $5 \mathrm{~mL}$ sterile water in a sterile vial. The conidial suspension was scraped by an L-shape inoculating needle several times and streaked across the water agar plate. The plate was incubated for $12 \mathrm{~h}$ to $24 \mathrm{~h}$ at $25^{\circ} \mathrm{C}$; after that, it was examined under a dissecting microscope (Olympus CX43). A lot of germinating conidia appeared on the inoculation, and by following the streaked lines using the low power of the microscope, single germinating conidia could be observed. Finally, identification of F. oxysporum cultures was accomplished (Niemeyer and De Andrade, 2016).

Soil and tomato root samples were taken from tomato growing areas in Blitar (156 masl), Karangploso (515 m a.s.l.), and Pujon (956 m.a.s.l.). Isolation was carried out using the method (El-shafey, 2020) with slight modifications in the medium. Isolation was carried out by growing the sample on PDA (Merck) media until pure isolates were obtained. This will be used for further investigations. 0.1uL of Fusarium isolates were then grown in water agar media for $24 \mathrm{~h}$, then a single spore from Fusarium was cut and grown on new PDA media in Petri dish for $7 \mathrm{~d}$ at $25^{\circ} \mathrm{C}$. The growing isolates were then used for DNA testing and stored in the refrigerator for collection and other purposes. Isolates aged $7 \mathrm{~d}$ were then harvested for DNA testing.

\subsection{Isolate preparation}

Isolates grown on PDA media (Merck) were then developed into PDB media (potato dextrose broth - Merck) and incubated in water bath shakers for $7 \mathrm{~d}$ to $9 \mathrm{~d}$ until the mycelium grew. The mycelium can be harvested, put into an Eppendorf tube, then added $500 \mathrm{~mL}$ Mili Q water and be ready for extraction with centrifuged at $10000 \mathrm{rpm}$ (1 $\mathrm{rpm}=1 / 60 \mathrm{~Hz}$ ) for $10 \mathrm{~min}$ (Hussain et al., 2012).

\subsection{Fungi DNA extraction}

PCR Preparation Based on isolate preparation, the supernatant was taken with a micropipette and crushed with pastel until it became colloidal. Colloids were added with Reagent 1 as much as $300 \mathrm{~mL}$, then homogenized using tips from the micropipette. Added $3 \mu \mathrm{L}$ of RNAse, homogenized using tips, and incubated for $30 \mathrm{~min}$ at $37^{\circ} \mathrm{C}$ in a water bath, then added Reagent 2 for $200 \mu \mathrm{L}$, strong shaking for $\pm 10 \mathrm{~min}$ set for $10 \mathrm{~min}$ at room temperature, put in the freezer for $20 \mathrm{~min}$. After freezing, added $250 \mu$ of chloroform and $250 \mu$ of phenol. It was homogenized for \pm 4 min, centrifuged (DLAB High-Speed Refrigerated Micro-Centrifuge D3024R) at $10000 \mathrm{rpm}$ for $10 \mathrm{~min}$ at the temperature of $14{ }^{\circ} \mathrm{C}$. The supernatant was taken, plus isopropanol, in half of the sample volume $(250 \mu \mathrm{L})$, then reversed slowly to homogeneous. Centrifuged at 10000 rpm for $10 \mathrm{~min}$, then the supernatant was removed. Added $50 \mu \mathrm{L}$ ethanol $99 \%$, then centrifuged with a speed of 10 $000 \mathrm{rpm}$ for $10 \mathrm{~min}$; the supernatant was disposed of by pouring. It was dried up by turning the microtube over the tissue by opening the lid for $\pm 30 \mathrm{~min}$. Added Nuclease free water as much as $100 \mu \mathrm{L}$ (lots) and $50 \mu \mathrm{L}$ (a little).

\subsection{Polymerase Chain Reaction}

The DNA obtained was then multiplied by a polymerase chain reaction. The primers used for this PCR process were ITS 1 and ITS primers 4. The primer ITS1 (5'-TCT GTA GGT GAA CCT GCG G3') and ITS4 (5'TCC TCC GCT TAT TGA TAT GC-3'). The PCR solution mixture was $1 \mathrm{uL}$ to $2 \mathrm{uL}$ primer, $5 \mathrm{uL}$ DNA samples, and $6 \mathrm{uL}$ PCR mix (Half reaction) (Singha et al., 2017). The PCR condition was run in 5 min $94{ }^{\circ} \mathrm{C}$ for predenaturation, then followed by 35 cycles where each cycle consisted of 30s, $94{ }^{\circ} \mathrm{C}$ for denaturation, 30 s, $50^{\circ} \mathrm{C}$ for annealing, and $1 \mathrm{~min}$ temperature $72{ }^{\circ} \mathrm{C}$ centigrade for extension; then ended with 1 min cycle with a temperature of $72{ }^{\circ} \mathrm{C}$. The particular annealing temperature was also tested at $48{ }^{\circ} \mathrm{C}$ as the annealing temperature recommended by primer pairs.

\subsection{Agarose Preparation}

mixed $1 \%$ agarose $(0.3 \mathrm{~g})$ with $30 \mathrm{~mL}$ TBE $1 \times$ (from Tris base and boric acid 10×) in an Erlenmeyer tube. Agarose was dissolved by heating it to the microwave for \pm 2 min until the solution was dissolved entirely then add ETBR $2 \mu \mathrm{L}$ and pour it into a gel mold into a gel mold that has been fitted with a comb The gel was allowed to hard for $\pm 30 \mathrm{~min}$.

\subsection{Electrophoresis preparation}

After the comb was removed from the mold, then the gel was transferred into the electrophoresis tank. The $3 \mu \mathrm{L}$ DNA solution was mixed with loading dye $1 \mu \mathrm{L}$ and $2 \mu \mathrm{L}$ on parafilm paper, then the mixture and marker were put into the agarose gel well. Adjust the position of the agarose gel in electrophoresis. After combining DNA loading, dye and water were inserted into the well. The electrophoresis device has adjusted the electrophoresis with $100 \mathrm{~V}$ and $25 \mathrm{~min}$ later running. Electrophoresis was complete. The agarose gel lifted in the agarose gel was brought into the doc gel illuminated with a UV- 
Transilluminator and gel photographed with the gel documentation to visualize the results.

\subsection{Measurement of concentration and purity of extracted DNA}

The concentration and purity of DNA extracted using NanoDrop with two different wavelengths, wavelengths 260 and 280. The purity of DNA can be determined by dividing the results of the NanoDrop measurements of both wavelengths (Srinivas et al., 2019), while the DNA concentration was obtained directly from the NanoDrop.

\subsection{Analyzing the results of reading Gel Doc}

Analyzing the results of reading Gel Doc was done qualitatively by observing and determining the band's size that comes out with PCR-electrophoresis results compared to the marker. This information was then compared with the literature to ascertain whether the target DNA location obtained was precisely the location of ITS (Adame-García, 2015).

\subsection{Sequencing the results of amplification of DNA samples}

The results of the DNA sample amplification obtained were then sent to PT. Indonesian Science Genetics for sequencing. The 1st Base company carried out the sequencing process, Axil Scientific Pte Ltd., Based in Singapore. The material used for DNA sequencing is BigDye ${ }^{\circledR}$ Terminator v3.1 Cycle Kit Chemistry.

\subsection{Data Analysis of Sequencing Results}

Sequencing results based on ITS 1 or ITS 4 primers for each isolate were aligned and then edited using Mega v.10 software by referring to the chromatogram and being converted to fasta. The data in the form of fasta were further analyzed by looking for similarities using the basic local alignment search tool (BLAST) program from the GeneBank Gen database owned by the National Center of Biotechnology Information / NCBI.

BLAST was used to determine which species has the closest homology. Ambiguous areas in parallel sequences were omitted from the analysis. The gap was considered missing data (Pinaria, et al., 2015). The phylogeny tree's evolutionary history was inferred based on the NeighborJoining method (Cañizares et al., 2015). The evolutionary distance was calculated using the Maximum Composite Likelihood method (Chala, et al., 2019). And it was in units of base substitution per site. Evolution analysis was carried out with the MEGA $X$ version application (Nirmaladevi, et al. 2016). Preparation of the genetic distance matrix $F$. oxysporum Karangploso sample with several species genes recorded in GenBank was also carried out using the MEGA X version application.

\section{Result and Discussion}

The isolates used in this research had the highest sporulation and growth rates from previous studies, namely those from roots and soil from three high, medium. and low land altitudes. (Henik et al., 2021). Morphologically, Fusarium species are identified by several morphological characteristics. One of the notable features is the development of various shapes and sizes of macro and microconidia. Other structures that they form are called chlamydospores spores (El Kichaoui et al., 2017; Raghu et al. 2016), and also identified based on the growth rate and their pigmentations on agar media (Leslie et al., 2008).

Moreover, morphological identification can be quite difficult among the Fusarium species (Lievens et al., 2008). The sequence information using ITS regions has been immensely used in the phylogeny and taxonomy of Fusarium species (Menezes et al., 2010) as ITS regions have successfully identified them (Chen et al., 2004). ITS is differentiated into ITS1 and ITS2 (genes $18 \mathrm{~S}$ to $5.8 \mathrm{~S}$ and 5.8S to 28S, respectively) (Hillis and Dixon, 1991). There are more than 172000 fungal ITS sequences present in Genbank. The result showed the thickness of DNA bands that varied from those showing thin bands to thick bands (Figure 1). The thickness of the tape is related to the concentration of DNA isolation results. The thin ribbon shows that the DNA concentration produced from the extraction process is low, while the thick band indicates the low concentration of DNA from extraction (Menu, et al., 2018).

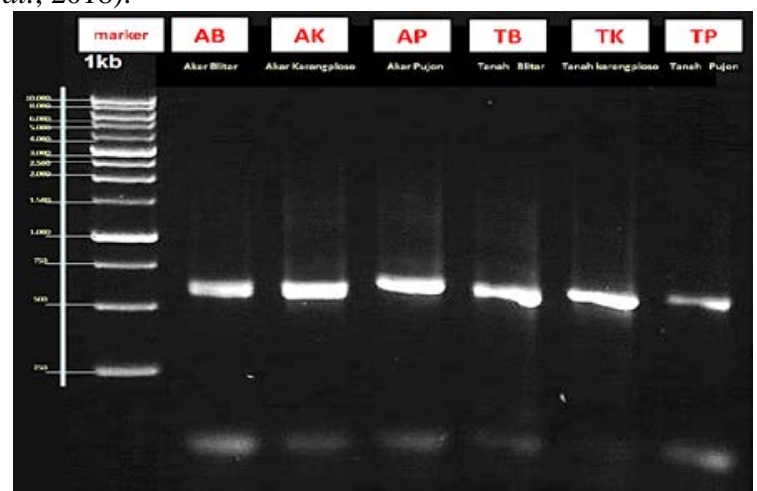

Figure 1. The amplification of Fusarium DNA samples using primary pairs ITS 1 and ITS 4 with an annealing temperature of $50 \mathrm{oC}$ at three different altitudes (156 m a.s.l, $515 \mathrm{~m}$ a.s.l. and 956 $m$ a.s.l.). $A B=$ Blitar root, $A K=$ Karangploso root, $A P=$ Pujon root, $\mathrm{TB}=$ Blitar soil, $\mathrm{TK}=$ Karangploso soil, $\mathrm{TP}=$ Pujon soil .

Electrophoresis results show a band with a smear (Figure 1.). Smear is the remainder of the solutions that are still carried during the isolation process and can also be degraded DNA during the isolation process (GonzálezMendoza, et al., 2015). The process of DNA degradation at the stage of isolation can be caused by mixing the solution using a vortex, which aims to help cell lysis so that some DNA comes out and is fragmented and causes smears when electrophoresed (Campbell et al., 2010).

The results of Fusarium sample DNA amplification with a temperature of $48{ }^{\circ} \mathrm{C}$ annealing in the Polymerase Chain Reaction (PCR) process showed no amplification in each sample DNA testedThe thin bands below show a size that is much smaller than $250 \mathrm{bp}$. Allegedly, these bands are a visual form of primers' formation during polymerized Chain Reaction (PCR). Primers-dimers are not the result of the desired target DNA amplification. It can be seen from the size of the resulting tape that it is between $500 \mathrm{bp}$ and $750 \mathrm{bp}$, but there are still smears. 


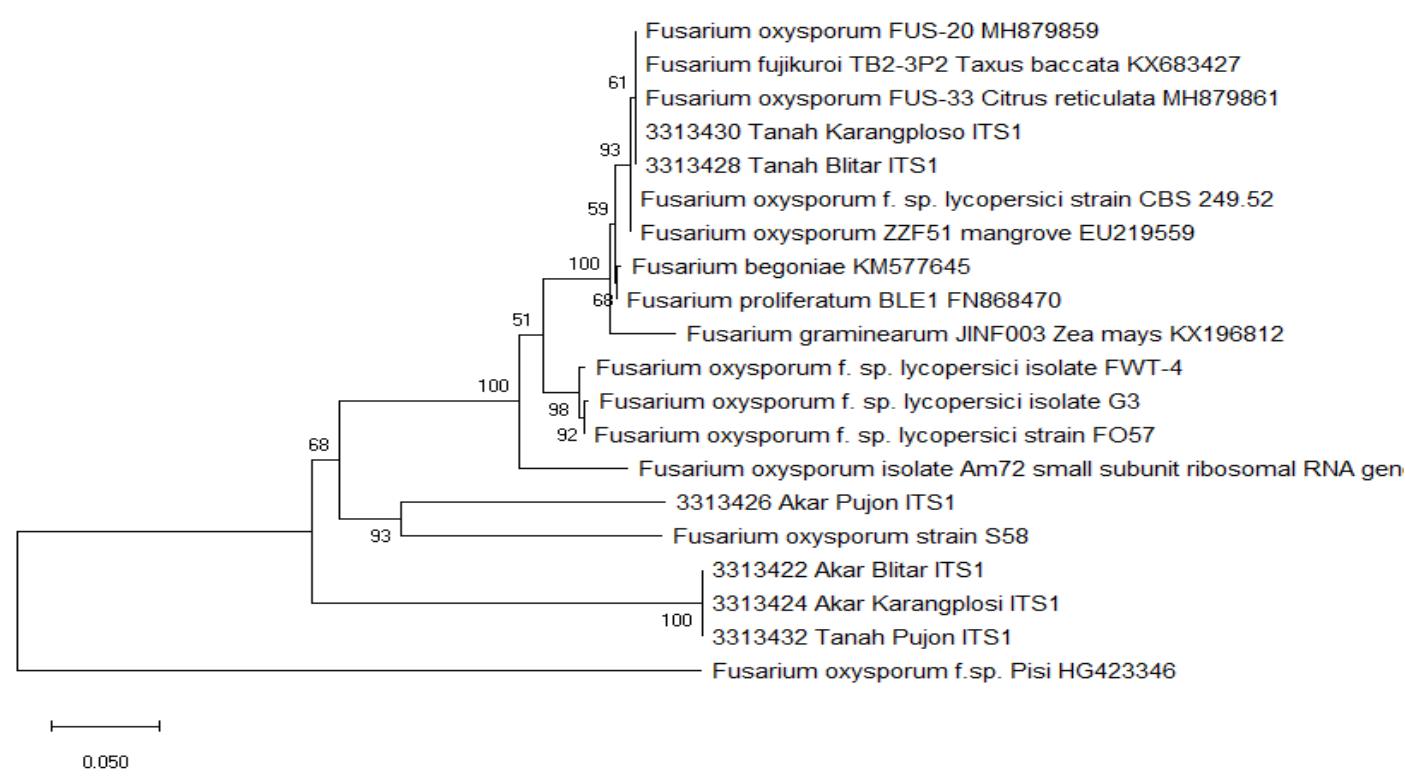

Figure 2. Phylogeny tree of Fusarium oxysporum at three different altitudes.

Based on the results of the evolution of tree evolution (phylogeny tree) and the similarity of nucleotide base sequences originating from the Internal Spacer (ITS) region, $\quad F$. oxysporum from six samples consisting of soil samples and roots of tomato plants at three different altitudes (156 m a.s.l., $515 \mathrm{~m}$ a.s.l. and 956 $\mathrm{m}$ a.s.l.), it was found that code 3313439 derived from Karangploso soil and code 3313428 originating from Blitar soil showed similarity of species with Fusarium oxysporum f.sp. lycopersici strain 249.52. A sample of 3313426 pujon roots has similarities with Fusarium oxysporum strain S58. Besides, samples of 3313422 Blitar roots, 3313424 roots of Karangploso, and 3313432 Pujon soil showed closeness to the species Fusarium oxysporum f.sp. pisi HG423346. That sample is in one clade with a nucleotide base sequence; other Fusarium oxysporum species have been recorded in the NCBI Genbank database. This third sample forms a monophyletic group with each other. In other parts of the branching, all groups incorporated in the $F$. oxysporum taxon species are polyphyletic with taxon members of Genus Fusarium sp. others. Knowledge of Fusarium wilt symptoms as a result of in depth is required. Tomato plants at the same altitudes have different closeness to Fusarium species or forma species in one area. It might affect the resistance of heat, fungicides, and different pathogenicity (Henik, et al., 2021) and show variations in pathogenicity, response to management systems, environment, and host differences (Hami et al., 2021).
Campbell et al., (2014) reported that a taxon is monophyletic if its single ancestor produces a whole derivative species in the taxon and not a species in another taxon, polyphyletic. If its members come from several ancestors that are not the same for all members, and paraphyletic if the taxon does not include species with grandmothers, the same ancestor in a member of a species towards another species. Branching like this can occur when two types of molecular characters specific to different homologous DNA species over time change due to various conditions (Nath, et al., 2017). The situation is like a point mutation that removes a nucleotide from the specific DNA sequences and inserts three adjacent nucleotides (Edel-Hermann and Lecomte, 2019). As a result of this situation, DNA sequences that are initially very similar have different lengths and sequences.

At the end of the branching of these three samples, a figure of $100 \%$ shows the high bootstrap value of this branching group. Bootstrap value is one of the measures introduced by (Fredricks, Smith, and Meier, 2005), which offers the stability value of a topology tree. The higher the bootstrap value in a branching, the more fulfilling the topology's validity level requirements. In other words, a high boost value (close to $100 \%$ ) does not mean showing the accuracy of a topology tree but rather indicates that each character information of each individual in the branching group "agrees" that a branching member is a group. 


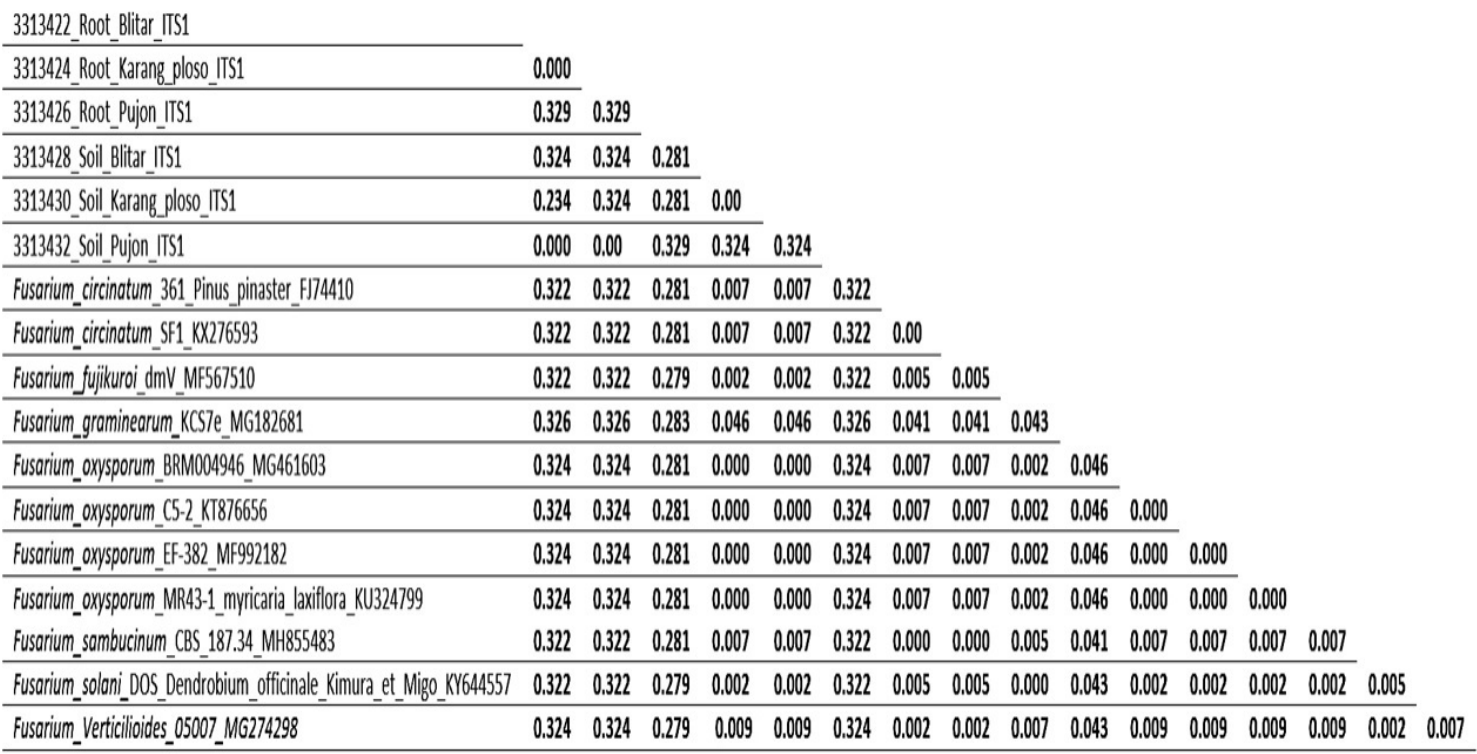

Figure 3. Genetic distance analysis of F. oxysporum at three different altitudes

Based on genetic distance analysis results, $F$. oxysporum from six sample-consisted soil samples and tomato plant roots at three different altitudes. Genetic distance matrix $F$. oxysporum with several specific Genes recorded from GenBank between 0.00 to 0.32 . The closest genetic distance is 0.00 for the sample. On the other hand, the genetic distance of the DNA sample $F$. oxysporum has a value of 0.32 , which is the farthest distance. which is of the genus Fusarium from other F. oxysporum species and then widens to other species.

In contrast, phylogeny's opening results show various levels of kinship between one species and another. The bootstrap value of the phylogeny tree is available between $51 \%$ and $100 \%$ the highest. According to Hafizi et al. (2013), the lower the genetic distance of species with other species, the closer the kinship distance.

According to Dharmayanti (2011), the farther the genetic distance of an individual or group from other individuals or groups, the more distant the kinship of the organism. Vice versa, the closer the genetic distance, the more closely related. Although the targeted gene's location is the same, differences in several nucleotide points in the gene sequence are prevalent mutations that cause this matter. Mutations are changes in genetic material that can be inherited and give rise to alternative forms of any gene. The more changes occur, the farther the genetic distance is from other species that share a common ancestor. Mutations result in a new variation of alleles, genes with the same location on the chromosome but whose properties vary (Stansfield et al., 2006).

\section{Conclusion}

From the results of molecular tests, information was obtained that all isolates found from different plant parts and from different altitudes were Fusarium oxysporum.

analysis shows Fusarium oxysporum f. sp. Lycopersici CBS 249.52 strain has the closest relationship in code 3313439 from Karangploso soil and code 3313428, which comes from Blitar soil. Besides, Fusarium oxysporum strain S58 has the closest relationship with the isolate 3313426 Pujon roots. Then samples of 3313422 Blitar roots, 3313424 Karangploso roots, and 3313432 Pujon soils showed proximity to the Fusarium oxysporum f.sp. pisi HG423346

\section{References}

Adame-García J., Rodriguez-Guerra R., Iglesias-Andreu LG, Ramos-Prado JM and Luna-Rodríguez M. 2015. Molecular identification and pathogenic variation of fusarium species isolated from Vanilla planifolia in Papantla Mexico. Bot. Sci. 93(3): 669-678.

Agrios G, 2005. Plant Pathology, fifth ed. Elsevier Academic Press, Burlington, MA, USA.

Animashaun BO, Popoola AR, Enikuomehin OA, Aiyelaagbe IOO, Imonmion J E. 2017. Induced resistance to Fusarium wilt (Fusarium oxysporum) in tomato using plant growth activator, Acibenzolar-S-methyl. Niger J Biotechnol 32:83-90

Aydi-Ben-Abdallah, Jabnoun-Khiareddine H and Daami-Remadi M. 2020. Fusarium wilt biocontrol and tomato growth stimulation, using endophytic bacteria naturally associated with Solanum sodomaeum and S. bonariense plants. Egypt J Biol Pest Co 30:113.

Biju VC, Fokkens L, Houterman PM, Rep M and Cornelissen BJC. 2017. Multiple evolutionary trajectories have led to the emergence of races in Fusarium oxysporum f. sp. lycopersici. Appl Environ Microbiol 83(4):e02548-16: 1-20.

Campbell NA, Reece JB, Urry LA, Cain M L, Wasserman SA, Minorsky P V and Jackson RB. 2010. Campbell biology. In: Campbell Biology (11th ed.). Pearson, London, UK

Cañizares MC, Gómez-Lama C, García-Pedrajas MD and PérezArtés E. 2015. Study of phylogenetic relationships among Fusarium oxysporum f. sp. dianthi Isolates: Confirmation of intrarace diversity and development of a practical tool for simple population analyses. Plant Dis. 99(6):780-787.

Chala A, Degefu T and Brurberg MB. 2019. Phylogenetically diverse Fusarium species associated with sorghum (Sorghum bicolor L. Moench) and finger millet (Eleusine coracana L. Garten) grains from Ethiopia. Diversity, 11(93):1-11

Chen CA, Chang CC, Wei NV, Chen C, Lein YT, Lin HE, Dai CF and Wallace C. 2004. Secondary structure and phylogenetic utility of the ribosomal internal transcribed spacer 2 (ITS2) in Scleractinian corals. Zool Stud 43(4): 759-771. 
Dharmayanti, I., 2011. Filogenetika molekuler: Metode taksonomi organisme berdasarkan sejarah evolusi [Molecular phylogenetics: The taxonomic method of organisms based on evolutionary history]. Wartazoa. 21 (1):1-10. [in Bahasa Indonesia]

Edel-Hermann V and Lecomte C. 2019. Current status of Fusarium oxysporum formae speciales and races. Phytopathology, 109(4):512-530.

Fredricks DN, Smith C and Meier A. 2005. Comparison of six DNA extraction methods for recovery of fungal DNA as assessed by quantitative PCR. J. Clin. Microbiol, 43(10): 5122-5128.

González-Mendoza D, Adame-García J, Rodriguez-Guerra R, Iglesias-Andreu LG, Ramos-Prado JM and Luna-Rodrígue M. 2010. A rapid method for isolation of total DNA from pathogenic filamentous plant fungi. Genet. Mol. Res, 9(1):162-166.

Hafizi R, Salleh B and Latiffah Z. 2013. Morphological and molecular characterization of Fusarium. solani and F. oxysporum associated with crown disease of oil palm. Braz. J. Microbiol. 44(3): 959-968.

Henik S, Erfan DS and Netnapis K. 2021. Variability of Fusarium oxysporum f. sp. lycopersici from different altitudes in East Java, Indonesia. E3S Web of Conf., 226(00023):1-9.

Hillis DM and Dixon MT.1991. Ribosomal DNA: Molecular evolution and phylogenetic inference. Q RevBiol. 66(4):411-453.

Hsuan HM, Salleh B and Zakaria L. 2011. Molecular identificationn of Fusarium species in Gibberella fujikuroi species complex from rice, sugarcane and maize from Peninsular Malaysia. Int. J. Mol. Sci. 12(10): 6722-6732.

Hussain MZ, Rahman MA, Islam MN, Latif MA and Bashar MA. 2012. Morphological and molecular identification of Fusarium oxysporum Sch. isolated from guava wilt in Bangladesh. Bangladesh J. Bot., 41(1):49-54.

Ignjatov M, Milosevic D, Nikolic Z, Gvozdanovic-Varga J, Jovicic D and Zdjelar G. 2012. Fusarium oxysporum as causal agent of tomato wilt and fruit rot. Pestic. Fitomed., 27(1): 25-31.

Kichaoui AE, Elnabris K, Shafie A, Fayyad N, Arafa M, and El Hindi M. 2017. Development of Beauveria bassiana based biofungicide against Fusarium wilt pathogens for Capsicum annuum, a promising approach toward vital biocontrol industry in Gaza Strip. IUG Journal of Natural Studies. 25(2):183-190.

Leslie JF and Summerell BA. 2006. Handbook Fusarium. Blackwell Publishing Professional. New Jersey, USA

Leslie JF and Summerell BA. 2008. The Fusarium Laboratory Manual. Wiley, New York.

Lievens B, Rep M and Tomma BP. 2008. Recent developments in the molecular discrimination of formae speciales of Fusarium oxysporum. Pest Manag Sci. 64(8):781-788.
Menezes JP, Lupatini M, Antoniolli' ZI, Blume' L, Junges E, Manzoni CG. 2010. Genetic variability in rDNA ITS region of Trichoderma spp. (Bio controle agent) and Fusarium oxysporum f. sp. chrysanthemi isolates. Cienc. e Agrotecnologia 34(1):132-139.

Menu E, Mary C, Toga I, Raoult D, Ranque S. and Bittar F. 2018. Evaluation of two DNA extraction methods for the PCR-based detection of eukaryotic enteric pathogens in fecal samples. BMC Res Notes, 11(1):4-9.

Nath N, Ahmed AU and Aminuzzaman FM. 2017. Morphological and physiological variation of Fusarium oxysporum f. sp. ciceri isolates causing wilt disease in chickpea. Int. J. Agric. Environ. Biotechnol., 2(1):202-212.

Nirmaladevi D, Venkataramana M, Srivastava RK, Uppalapati SR, Gupta VK, Yli-Mattila T, Chandra NS. 2016. Molecular phylogeny, pathogenicity, and toxigenicity of Fusarium oxysporum f. sp. Lycopersici. Sci. Rep, 6(21367): 1-14.

Pinaria AG, Laurence MH, Burgess LW and Liew ECY. 2015. Phylogeny and origin of Fusarium oxysporum f. sp. vanillae in Indonesia. Plant Pathol., 64(6):1358-1365.

Prihatna C, Barbetti MJ, and Barker SJ. 2018. A novel tomato Fusarium wilt tolerance gene. Front. Microbiol. 9(1226): 1-11.

Raghu S, Benagi, V and Nargund, V. 2016. Cultural, morphological and pathogenic variability among the isolates of Fusarium solani causing wilt disease of Chilli (Capsicum annuum L.). J. Pure Appl. Microbiol. 10(1):599-604.

Singha IM, Kakoty Y, Unni BG, Das J and Kalita MC. 2016. Identification and characterization of Fusarium sp. using ITS and RAPD causing fusarium wilt of tomato isolated from Assam, North East India. J Genet Eng Biotechnol. 14(1): 99-105.

Sohail A. Alsohaili and Bayan M. Bani-Hasan. 2018. Morphological and molecular identification of fungi isolated from different environmental sources in the Northern Eastern desert of Jordan. Jordan J. Biol. Sci. 11(3): 329-337.

Srinivas C, Nirmala DD, Narasimha MK., Mohan CD, Lakshmeesha TR, Singh BP and Chandra NS. 2019. Fusarium oxysporum f. sp. lycopersici causal agent of vascular wilt disease of tomato: Biology to diversity- A review. Saudi J Biol Sci., 26(7):1315-1324.

Stansfield, William D., Jaime S., Raul J., 2006. Biologi Molekuler dan Sel [Molecular and Cell Biology]. Penerbit Erlangga, Jakarta, Indonesia [in Bahasa Indonesia].

Teixeira LM, Coelho L, and Tebaldi TD. 2015. Characterization of Fusarium oxysporum isolates and resistance of passion fruit genotypes to fusariosis. Rev. Bras. Frutic. 39(3): e-415:1-11. 